\title{
Disease Potential of Soil- and Tuberborne Inocula of Colletotrichum coccodes and Black Dot Severity on Potato
}

\author{
Nadav Nitzan, Tom F. Cummings, and Dennis A. Johnson, Department of Plant Pathology, Washington State Uni- \\ versity, Pullman 646430
}

\begin{abstract}
Nitzan, N., Cummings, T. F., and Johnson, D. A. 2008. Disease potential of soil- and tuberborne inocula of Colletotrichum coccodes and black dot severity on potato. Plant Dis. 92:1497-1502.

Inoculum of Colletotrichum coccodes, the cause of potato black dot, is soil- or tuberborne. Understanding the disease potential of sources of inocula is crucial for developing disease management strategies and resistance screening techniques. Two hypotheses were tested in this study: (i) soilborne inoculum causes more disease than tuberborne inoculum and (ii) black dot severity is related to the concentration of soilborne inoculum. Trials were conducted in the greenhouse with standardized inoculum. Plants grown in infested soil had more sclerotia on roots than plants grown from infected tubers in three of four trials. In general, plants grown in infested soil produced fewer tubers and lower yields than the noninoculated plants. Plants grown from infected tubers produced similar numbers of tubers as the noninoculated plants in all trials, and had reduced yields in one of the four trials. Increasing concentrations of soilborne inoculum had a nonlinear association with disease development. Foliar symptoms, sclerotial density on roots, and sclerotial development on stems did not increase when soil inoculum exceeded 0.5 or $1.7 \mathrm{~g} /$ liters of soil. In this study, soilborne inoculum caused more disease than tuberborne inoculum and disease severity remained constant above a threshold of soilborne inoculum.
\end{abstract}

Potato black dot is caused by the fungus Colletotrichum coccodes (Wallr.) S. Hughes (6). The disease is of economic concern in several major potato-producing regions in North America (3,14-17). Black dot can decrease tuber yield weight between 16 to $30 \%$ due to early death of the crop $(14,19,25,29,34,36,37)$ and may also reduce the quality of tubers of white- and red-skinned cultivars due to gray-brown blemishes (19).

Black dot develops from soil-, tuber-, or airborne inocula $(1,2,8,9,13,15,33,35-$ 37). The pathogen is generally introduced into noninfested soils by infected potato tubers (37). The belowground parts of potato plants are infected relatively early in the season but these initial infections do not result in chlorotic or necrotic foliar symptoms $(1,25)$. As the plants enter the tuber bulking stage and the foliage starts to senesce (22), the pathogen colonizes aboveground stems (25). By the end of the season, sclerotia are visible on roots, stolons, and stems $(23,25,29)$. Tubers may be infected externally, resulting in brown-silver blemishes, or internally through vascular tissues near the stolon end $(11,19,35)$.

Corresponding author: N. Nitzan

E-mail: nadav.nizan@ars.usda.gov

Accepted for publication 3 July 2008.

doi:10.1094/PDIS-92-11-1497

(c) 2008 The American Phytopathological Society
The aggressiveness of soil- and tuberborne inocula and their relative influence on black dot severity has been debated $(7,9,23,33)$. Dashwood et al. (7) reported that inoculum source (tuber or soil) did not affect the severity of black dot. Read and Hide (33) and Denner et al. (8) concluded that soilborne inoculum caused more disease than tuberborne inoculum. Nitzan et al. (23) supported the latter view in studies using two tuber generations (G1 and G3) with differing levels of tuberborne inoculum. Black dot became progressively more severe with continued potato production in a field.

Interactions between $C$. coccodes isolates and potato cultivars (1) and varying levels of aggressiveness among C. coccodes isolates (3) have been reported. The association between genetic variation of $C$. coccodes isolates and disease severity was studied in depth by Nitzan et al. $(26,28,29)$. Two independent studies, one using isolates from Israel and Europe and the other using North American isolates, demonstrated that populations of $C$. coccodes were composed of vegetative compatibility groups (VCGs) with diverse genetic, pathogenic, and physiological traits $(12,26,28,29)$. To date, the association among the genetic background of $C$. coccodes isolates, inoculum source, potato genetic background, and black dot severity is not well characterized.

In this study, two hypotheses were tested: (i) soilborne inoculum has a higher disease-causing potential than tuberborne inoculum and (ii) black dot severity is positively related to the number of $C$. $\mathrm{coc}$ codes propagules in the soil. The rational to further examine the impact of tuber- and soilborne inocula originated from new information that the North American and the European-Israeli populations of $C$. coccodes may be genetically different (29). In addition, the majority of the potato cultivars used in Washington, Oregon, or Idaho by the potato industry are russet skin potatoes. These cultivars do not commonly demonstrate skin blemishes as do the nonrusset cultivars commonly used in Europe or Israel. Furthermore, all previous studies that examined this hypothesis were conducted in the field. This study was conducted in the greenhouse, under controlled environment, with genetically characterized $C$. coccodes isolates $(12,29)$ and with standardized inoculum levels.

\section{MATERIALS AND METHODS}

All trials were conducted in a greenhouse on the Pullman campus of Washington State University. Trials comparing inoculum sources (soil versus tuber) were conducted in each of four years (2003 to 2006) using nuclear tubers of the blackdot-susceptible cv. Russet Burbank. Two trials relating soilborne inoculum concentration with disease severity were conducted in 2006 using nuclear tubers of the black-dot-susceptible cv. Russet Ranger. Nuclear tubers of both cultivars were commercially produced in Montana in a certified potato seed-tuber program. The nuclear tubers were the progeny of tissuecultured potato plantlets that were grown in a greenhouse and were certified pathogen free. All tubers used in these trials were washed with tap water and soap and surface sterilized in $1 \% \mathrm{NaClO}$ for $10 \mathrm{~min}$. The tubers were cut into pieces weighing approximately $24 \mathrm{~g}$ and were allowed to suberize for $48 \mathrm{~h}$ at $10^{\circ} \mathrm{C}$ before planting. A single tuber piece was planted in each pot about $2.5 \mathrm{~cm}$ deep. The pots were 3.6 liters $(20.5 \times 15.5 \mathrm{~cm}$, lower and upper diameter, respectively, and $16 \mathrm{~cm}$ in height) and were filled with Sunshine LC1 potting mix (Sun-Gro Horticulture, Canada, Ltd.). At planting, $12 \mathrm{~g}$ of the slow release fertilizer Osmocote (16-16-16 NPK; Scotts) was added, and $3 \mathrm{~g}$ were added 2 months later. All plants were cut to one stem a month after emergence in order to standardize the number of stems per plant for yield purposes. Temperatures were recorded with a "Watch Dog" data 
logger (model 150; Spectrum Technologies, Inc., East Plainfield, IL). Day temperatures were recorded from 7:00 a.m. to 7:00 p.m. and night temperatures were recorded from 7:00 p.m. to 7:00 a.m. Night and day temperatures in 2003, 2004, 2005, and 2006 ranged from 16 to 22,21 to 25 , 14 to 23 , and 15 to $24^{\circ} \mathrm{C}$, respectively.

Soilborne inoculum was prepared by subculturing isolates C19, C56, and C59 (North American VCGs 1, 2, and 2, respectively; 29) on $1 \%$ potato dextrose agar (PDA) at $25^{\circ} \mathrm{C}$ in the dark. Five days later, conidia were aseptically washed from the agar surface and the colonized agar was used to inoculate twice-autoclaved rye grains (29). Then, 3 to 4 weeks later, colonized grains were air dried for 2 weeks at room temperature. The dried inoculum of each isolate was stored in separate sealed plastic bags at room temperature until used. The number of sclerotia produced on each rye grain was quantified with the aid of a stereoscope to be approximately 250 .

Tuberborne inoculum was produced by subculturing isolates C19, C56, and C59 of C. coccodes individually on $1 \% \mathrm{PDA}$ at $25^{\circ} \mathrm{C}$ in the dark. A week later, conidia were washed from the agar surface and filtered through four layers of sterile cheesecloth. The concentrations of the conidial suspensions were adjusted to 1.3 $\times 10^{5}$ conidia/ml with the aid of a hemacytometer. Immediately after the stolon ends of tubers were removed with a sterile scalpel to expose vascular tissues, a sterilized piece of filter paper amended with $50 \mu \mathrm{l}$ of the conidial suspension was applied to the wound. Tubers were incubated in a moist chamber at $25^{\circ} \mathrm{C}$ in the dark for $48 \mathrm{~h}$. A successful infection was apparent by the appearance of brownish, sunken lesions and, in some cases, sclerotia at the inoculation court within $48 \mathrm{~h}$. Tissue samples from all tubers were transferred to $1 \%$ PDA to verify infection. Infected tubers were stored at $10^{\circ} \mathrm{C}$ until used.

Trials comparing inoculum sources (soil versus tuber) were planted from late February to mid May and were terminated 99 , 134,150 , and 150 days after planting in 2003, 2004, 2005, and 2006, respectively. Soilborne inocula consisted of $15 \mathrm{~g}$ of colonized rye grain (about 650 grains). The treatments consisted of infesting soils and inoculating tubers with each $C$. coccodes isolate as follows: (i) infested soil + infected tuber (soil+/tuber+), (ii) infested soil + noninfected tuber (soil+/tuber-), (iii) noninfested soil + infected tuber (soil/tuber+), and (iv) noninfested soil + noninfected tuber (soil-/tuber-; non-inoculated

Table 1. Length of stems from the soil surface on which sclerotia were visible on Russet Burbank potato plants that grew from inoculated or noninoculated tubers in infested or noninfested soil with one of three isolates of Colletotrichum coccodes in 2005 in the greenhouse ${ }^{\mathrm{x}}$

\begin{tabular}{lccccc}
\hline \multicolumn{2}{l}{ Inoculum source treatment } & & \multicolumn{3}{c}{ Sclerotial development on aboveground stem by isolate $(\mathbf{c m})^{\mathbf{z}}$} \\
\cline { 1 - 2 } \cline { 5 - 6 } Soil & Tuber & & C 19 & C 56 & C 59 \\
\hline+ & + & & $10 \mathrm{~b} \mathrm{~A}$ & $21 \mathrm{a} \mathrm{A}$ & $15 \mathrm{ab} \mathrm{AB}$ \\
+ & - & & $13 \mathrm{ab} \mathrm{A}$ & $7 \mathrm{~b} \mathrm{~B}$ & $19 \mathrm{a} \mathrm{A}$ \\
- & + & & $12 \mathrm{a} \mathrm{A}$ & $11 \mathrm{a} \mathrm{B}$ & $9 \mathrm{a} \mathrm{B}$ \\
\hline
\end{tabular}

${ }^{x}$ Two-way analysis of variance was carried out in SAS (SAS Institute Cary, NC). The means were contrasted and separated by Fischer's protected $t$ tests (least significant difference, $P<0.05$ ). The noninoculated control plants were excluded from the analysis. This was done because sclerotia on stems recorded disease severity via pathogen signs, and the control plants were not inoculated with the pathogen.

y Soil $+=$ infested soil, soil $-=$ noninfested soil, tuber $+=$ inoculated tuber, and tuber $-=$ noninoculated tuber.

${ }^{\mathrm{z}}$ Height $(\mathrm{cm})$ up the stem from soil level that sclerotia developed. Different lowercase letters (rows) represent differences among the isolates within each inoculum source treatment. Different capital letters (column) represent differences among inoculum source treatments within each isolate.

Table 2. Length of stems from the soil surface on which sclerotia were visible on Russet Burbank potato plants that grew from inoculated or noninoculated tubers in infested or noninfested soil with one of three isolates of Colletotrichum coccodes in 2006 in the greenhouse ${ }^{\mathrm{x}}$

\begin{tabular}{|c|c|c|c|c|}
\hline \multicolumn{2}{|c|}{ Inoculum source treatment ${ }^{\mathrm{y}}$} & \multicolumn{3}{|c|}{ Sclerotial development on aboveground stem by isolate $(\mathrm{cm})^{2}$} \\
\hline Soil & Tuber & C 19 & C 56 & C 59 \\
\hline+ & + & 6 a A & 7 a A & 6 a B \\
\hline+ & - & $4 \mathrm{~b} \mathrm{~A}$ & $6 \mathrm{~b} \mathrm{~A}$ & 11 a A \\
\hline- & + & 4 a A & 3 a B & 3 a B \\
\hline
\end{tabular}

${ }^{x}$ Two-way analysis of variance was carried out in SAS (SAS Institute Cary, NC). The means were contrasted and separated by Fischer's protected $t$ tests (least significant difference, $P<0.05$ ). The noninoculated control plants were excluded from the analysis. This was done because sclerotia on stems recorded disease severity via pathogen signs, and the control plants were not inoculated with the pathogen.

y Soil $+=$ infested soil, soil $-=$ noninfested soil, tuber $+=$ inoculated tuber, and tuber $-=$ noninoculated tuber.

${ }^{\mathrm{z}}$ Height $(\mathrm{cm})$ up the stem from soil level that sclerotia developed. Different lowercase letters (rows) represent differences among the isolates within each inoculum source treatment. Different capital letters (column) represent differences among inoculum source treatments within each isolate. control plants). Treatments were arranged in a three-by-four factorial in a randomized complete block design with eight replicated blocks in 2003 to 2005 and six replicated blocks in 2006. The three isolates (C19, C56, and C59) and the four inoculum source combinations (soil+/tuber+, soil+/tuber-, soil-/tuber+, and soil-/tuber-) were the main fixed effects.

Trials relating soilborne inoculum concentration to disease severity were planted in early and late March 2006 (trials 1 and 2 , respectively) and terminated 160 days after planting. Rye grains colonized with isolate $\mathrm{C} 56$ were added to the soil at quantities of $0,0.5,1.7,5$, and 8.3 grams per liter of soil, or approximately $0,0.6 \times 10^{4}$, $1.8 \times 10^{4}, 5.4 \times 10^{4}$, and $9 \times 10^{4}$ sclerotia per liter of soil. Inoculum concentrations were replicated five times in a randomized complete block design.

Disease severity was evaluated after plants died and dried in the pots on the greenhouse bench. The density of sclerotia was visually evaluated on a 0 -to-5 scale, where $0=$ no sclerotia, $1=1$ to $10 \%, 2=$ 11 to $30 \%, 3=31$ to $50 \%, 4=51$ to $75 \%$, and $5=76$ to $100 \%$ of the surface area was covered with sclerotia. The length of the stem from the soil surface upward on which sclerotia were visible was measured. Foliar symptoms were assessed in the trials concerning soilborne inoculum concentrations with disease severity but not when comparing inoculum sources. The percentage of chlorosis or necrosis was scored at 7- to 10-day intervals starting with the first appearance of symptoms, and the area under the disease progress curve (AUDPC) was calculated using the formula AUDPC $=\sum\left[\left(y_{i}+y_{i+1}\right) / 2\right]^{*}\left(t_{i+1}-t_{i}\right)(4)$, where $y_{i}=$ initial severity of symptoms and $t_{i}=$ initial time of symptoms appearance. Foliar symptoms were scored eight times from 6 May to 6 July 2006 in the first trial and seven times from 30 May to 12 July 2006 in the second trial. Total tuber weight and number of progeny tubers were recorded for each replication. The averages per treatment were calculated.

Data from the inoculum source trials (soil versus tuber) were analyzed with Proc GLM in SAS (SAS Institute; Cary; NC). Isolates (C19, C56, and C59) and inoculum sources (soil and tuber) were the main fixed effects. Each trial was analyzed separately due to interactions between the main fixed effects and the year of the trial. In the presence of interactions between inoculum sources and isolates, each isolate was analyzed separately. Where there was no interaction between inoculum sources and isolates, data of the three isolates were combined and analyzed jointly. The model used in Proc GLM was: response = block + inoculum source + isolate + inoculum source $x$ isolate. The noninoculated control plants were excluded from the analyses of sclerotial development on stem and sclerotial densities on roots. Sclerotial densi- 
ties on roots were recorded as ordinal data (0-to-5 scale) and therefore were analyzed nonparametrically using the KruskalWallis analysis of variance by ranks (39). The values of the observations were ranked with Proc Rank in SAS, and analysis of variance was carried out on the ranked values. All means were separated with Fischer's protected $t$ test (least significant difference) at a significant level of $5 \%$. The data of the soilborne inoculum concentration trials were tested with linear and nonlinear regressions in Sigma Plot (Sigma Plot Version 10; Systat Software Inc.). The nonlinear regression analyses were carried out with a three-parameter logistic model (31).

\section{RESULTS}

Inoculum source (soil versus tuber). Interactions between fungal isolates and inoculum source were recorded in 2005 and 2006 for the length of the stem from the soil surface upward on which sclerotia were visible (sclerotia on aboveground stem) (Tables 1 and 2). Isolate C56 produced significantly $(P<0.05)$ more sclerotia on aboveground stems when its inoculum originated from a combination of soil and seed tuber (soil+/seed+) or the soil (soil+/seed-) than from only the seed tuber (soil-/seed+) in both years (Tables 1 and 2). Isolate $\mathrm{C} 59$ produced more $(P<0.05)$ sclerotia on aboveground stems when its inoculum originated from only the soil (soil+/seed-) than from only the seed tuber (soil-/seed+) in both years (Tables 1 and 2). In addition, isolate C59 produced significantly $(P<0.05)$ more sclerotia on aboveground stems than isolate C56 when their inoculum originated from the soil both years.

Data of sclerotial density on roots, the number of progeny tubers and the total weight of progeny tubers were combined for all three isolates of $C$. coccodes due to lack of interactions. Sclerotial density on roots was greater $(P<0.05)$ in the presence of soilborne inoculum (soil+/tuber+ or soil+/tuber-) than in its absence (soil-/ tuber+) in three of four years $(2003,2005$, and 2006; Table 3). In 2003 and 2006, sclerotial densities on roots were greater $(P$ $<0.05$ ) in infested soil (soil+/tuber+ and soil+/tuber-) than in noninfested soil (soil-/ tuber+). In 2005, sclerotial densities on roots were greater $(P<0.05)$ on plants grown from infected seed tubers in infested soil (soil+/tuber+) than on plants grown from infected seed tubers only (soil-/tuber+). Sclerotial densities on roots did not differ $(P>0.05)$ between inoculum sources for the isolates in 2004.

Plants grown in infested soil (soil+/ tuber+ and soil+/tuber-) produced significantly $(P<0.05)$ fewer progeny tubers than noninoculated controls (soil-/tuber-) in 2 of 4 years (Table 3 ). In contrast, plants grown from infected seed tubers (soil-/ tuber+) produced the same $(P>0.05)$ number of progeny tubers as the noninoculated controls (soil-/tuber-) all 4 years.

Tuber yield weight was significantly $(P$ $<0.05)$ reduced when inoculum originated from the soil (soil+/tuber+ and soil+/ tuber-) compared with the noninoculated controls (soil-/tuber-) in 3 of 4 years (in 2004, 2005, and 2006) (Table 3). In contrast, tuber yield weight was significantly reduced $(P<0.05)$ in only 1 of 4 years (2004) when inoculum originated from the seed tuber (soil-/tuber+) when compared with the noninoculated controls (soil-/ tuber-). In 2005, plants grown in infested soils (soil+/tuber-) had less tuber yield

Table 4. Selection of models to describe the relationship between soilborne inoculum concentration and the development of foliar chlorosis and necrosis recorded as area under the disease progress curve in trials 1 and 2 in 2006 in the greenhouse ${ }^{\mathrm{z}}$

\begin{tabular}{lcccccccc}
\hline & \multicolumn{3}{c}{ Trial 1 } & & \multicolumn{3}{c}{ Trial 2 } \\
\cline { 2 - 3 } \cline { 7 - 8 } Model & MSE & $\boldsymbol{R}^{\mathbf{2}}$ & $\boldsymbol{P r}>\boldsymbol{F}$ & & MSE & $\boldsymbol{R}^{\mathbf{2}}$ & $\boldsymbol{P r}>\boldsymbol{F}$ \\
\hline Linear & 20,012 & 0.6 & $<0.0001$ & & 7,337 & 0.56 & $<0.0001$ \\
Sigmoid & 14,010 & 0.74 & $<0.0001$ & & 5,775 & 0.7 & $<0.0001$ \\
\hline
\end{tabular}

${ }^{\mathrm{z}}$ Regression analysis was conducted using the Sigma Plot statistical package (Sigma Plot Version 10; Systat Software Inc). All inferences were conducted at a significant level of 5\%. MSE = mean square error of the residuals, $R^{2}=$ the regression goodness of fit, and $\operatorname{Pr}>F=P$ value of the regression.

Table 3. Sclerotial density on roots, number of progeny tubers, and total tuber weight of Russet Burbank potato grown from infected or noninfected tubers in infested or noninfested soil with three different isolates of Colletotrichum coccodes in the greenhouse in 2003, 2004, 2005, and 2006 ${ }^{\mathrm{w}}$

\begin{tabular}{|c|c|c|c|c|c|c|c|c|c|c|c|c|c|}
\hline \multicolumn{2}{|c|}{ Inoculum source ${ }^{x}$} & \multicolumn{4}{|c|}{ Sclerotial density on roots $(0-5)^{y}$} & \multicolumn{4}{|c|}{ Average number of progeny tubers } & \multicolumn{4}{|c|}{ Total progeny tuber yield weight $(\mathrm{g})^{\mathrm{z}}$} \\
\hline Soil & Tuber & 2003 & 2004 & 2005 & 2006 & 2003 & 2004 & 2005 & 2006 & 2003 & 2004 & 2005 & 2006 \\
\hline+ & + & $3.7 \mathrm{a}$ & $3.3 \mathrm{a}$ & $3.5 \mathrm{a}$ & $4.8 \mathrm{a}$ & $14 \mathrm{a}$ & $4 \mathrm{a}$ & $16 \mathrm{~b}$ & $12 \mathrm{c}$ & $361 \mathrm{a}$ & $184 \mathrm{~b}$ & $566 \mathrm{bc}$ & $521 \mathrm{~b}$ \\
\hline+ & - & $3.6 \mathrm{a}$ & $3.3 \mathrm{a}$ & $3.2 \mathrm{ab}$ & $4.8 \mathrm{a}$ & $14 \mathrm{a}$ & $4 \mathrm{a}$ & $14 \mathrm{~b}$ & $12 \mathrm{bc}$ & $379 \mathrm{a}$ & $203 \mathrm{~b}$ & $542 \mathrm{c}$ & $518 \mathrm{~b}$ \\
\hline - & + & $2.5 \mathrm{~b}$ & $3.5 \mathrm{a}$ & $2.6 \mathrm{a}$ & $3.9 \mathrm{~b}$ & $12 \mathrm{a}$ & $4 \mathrm{a}$ & $20 \mathrm{a}$ & $14 \mathrm{ab}$ & $362 \mathrm{a}$ & $174 \mathrm{~b}$ & $601 \mathrm{ab}$ & $565 \mathrm{ab}$ \\
\hline - & - & 1.7 & 0 & 1.4 & 1.5 & $14 \mathrm{a}$ & $5 \mathrm{a}$ & $19 \mathrm{a}$ & $15 \mathrm{a}$ & $382 \mathrm{a}$ & $274 a$ & $614 a$ & $586 \mathrm{a}$ \\
\hline
\end{tabular}

${ }^{w}$ Statistical analysis was carried out using Proc GLM in SAS (SAS Institute, Cary, NC). Average number of progeny tubers and total progeny tubers yield weight were analyzed as continuous data. Sclerotial density on roots was analyzed nonparametrically (39). The noninoculated control plants were excluded from the analyses of sclerotial densities on roots. This was done because sclerotia on stems and roots recorded disease severity via pathogen signs, and the control plants were not inoculated with the pathogen. All means were separated using Fischer's protected $t$ tests (least significant difference, $\alpha=0.05$ ). Different lowercase letters within columns represent significant statistical differences among the inoculum source treatments.

${ }^{\mathrm{x}}$ Inoculum source: soil $+/$ tuber $+=$ presence of $C$. coccodes in the soil and the tuber, soil $+/$ tuber $-=$ presence of $C$. coccodes only in the soil, soil- /tuber + $=$ presence of $C$. coccodes only in the tuber, and soil $-/$ tuber $-=$ noninoculated control plants.

y Sclerotial density on roots was scored visually on a 0 -to-5 scale, where $0=$ no sclerotia and $1=1$ to $10 \%, 2=11$ o $30 \%, 3=31$ o $50 \%, 4=51$ o $75 \%$, and 5 $=760100 \%$ of the surface area covered with sclerotia.

${ }^{z}$ In 2005 , the yield of plants from the soil $+/$ tuber + treatment was notably lower $(P=0.059)$ than the yield of plants grown in the soil- / tuber + treatment. In 2006, total yield of plants from soil $+/$ tuber + and soil $+/$ tuber - treatments was lower than the total yield of plants from soil $-/$ tuber + as indicated by a single degree of freedom contrast $(P=0.04$, and 0.02 , respectively). 
quately $(P<0.05)$ described the relationship of AUDPC to soilborne inoculum density (Table 4; Fig. 1).

The sclerotial density on the roots increased as the concentration of soilborne inoculum increased from 0 to $0.5 \mathrm{~g} / \mathrm{liter}$ and then leveled out at inoculum concentrations ranging between 0.5 and $1.7 \mathrm{~g} / \mathrm{liter}$ (Fig. 2). The relationship of sclerotial density on the root to soilborne inoculum concentration was explained $(P<0.05)$ by the sigmoid model (Table 5; Fig. 2).

The length of stem with visible sclerotia of the pathogen increased as soilborne inoculum concentration increased from 0 to $0.5 \mathrm{~g} /$ liter and did not continue to in- crease at inoculum levels above $0.5 \mathrm{~g} / \mathrm{liter}$ (Fig. 3). The relationship of the stem height to soilborne inoculum concentration followed the sigmoid model $(P<0.05$; Table 6).

\section{DISCUSSION}

Soilborne inoculum of $C$. coccodes was demonstrated to be potentially more aggressive than tuberborne inoculum in this study. Field work from Great Britain (33), South Africa (9), and North America (23) similarly indicated that soilborne inoculum had a higher potential to cause black dot than tuberborne inoculum. In contrast, only Dashwood et. al. (7) argued that in-

Table 5. Selection of models to describe the relationship between soilborne inoculum concentration and sclerotial density on the roots in trials 1 and 2 in 2006 in the greenhouse ${ }^{z}$

\begin{tabular}{lccccccc}
\hline & \multicolumn{3}{c}{ Trial 1 } & & \multicolumn{3}{c}{ Trial 2 } \\
\cline { 2 - 5 } \cline { 7 - 8 } Model & MSE & $\boldsymbol{R}^{\mathbf{2}}$ & $\boldsymbol{P r}>\boldsymbol{F}$ & & MSE & $\boldsymbol{R}^{\mathbf{2}}$ & $\boldsymbol{P r}>\boldsymbol{F}$ \\
\hline Linear & 2.03 & 0.22 & 0.02 & & 1.6 & 0.3 & 0.0051 \\
Sigmoid & 0.08 & 0.97 & $<0.0001$ & & 0.16 & 0.93 & $<0.0001$ \\
\hline
\end{tabular}

${ }^{\mathrm{z}}$ Regression analysis was conducted using the Sigma Plot statistical package (Sigma Plot Version 10; Systat Software Inc). All inferences were conducted at a significant level of 5\%. MSE $=$ mean square error of the residuals, $R^{2}=$ the regression goodness of fit, and $\operatorname{Pr}>F=P$ value of the regression.

Table 6. Selection of models to describe the relationship between soilborne inoculum concentration and the length of stems from the soil surface on which sclerotia were visible in trials 1 and 2 in 2006 in the greenhouse ${ }^{\mathrm{z}}$

\begin{tabular}{|c|c|c|c|c|c|c|}
\hline \multirow[b]{2}{*}{ Model } & \multicolumn{3}{|c|}{ Trial 1} & \multicolumn{3}{|c|}{ Trial 2} \\
\hline & MSE & $R^{2}$ & $P r>F$ & MSE & $R^{2}$ & $\operatorname{Pr}>\boldsymbol{F}$ \\
\hline Linear & 4.4 & 0.42 & 0.0006 & 18.9 & 0.2 & 0.03 \\
\hline Sigmoid & 2.67 & 0.66 & $<0.0001$ & 13.5 & 0.46 & 0.002 \\
\hline
\end{tabular}

${ }^{\mathrm{z}}$ Regression analysis was conducted using the Sigma Plot statistical package (Sigma Plot Version 10; Systat Software Inc). All inferences were conducted at a significant level of 5\%. MSE $=$ mean square error of the residuals, $R^{2}=$ the regression goodness of fit, and $\operatorname{Pr}>F=P$ value of the regression.

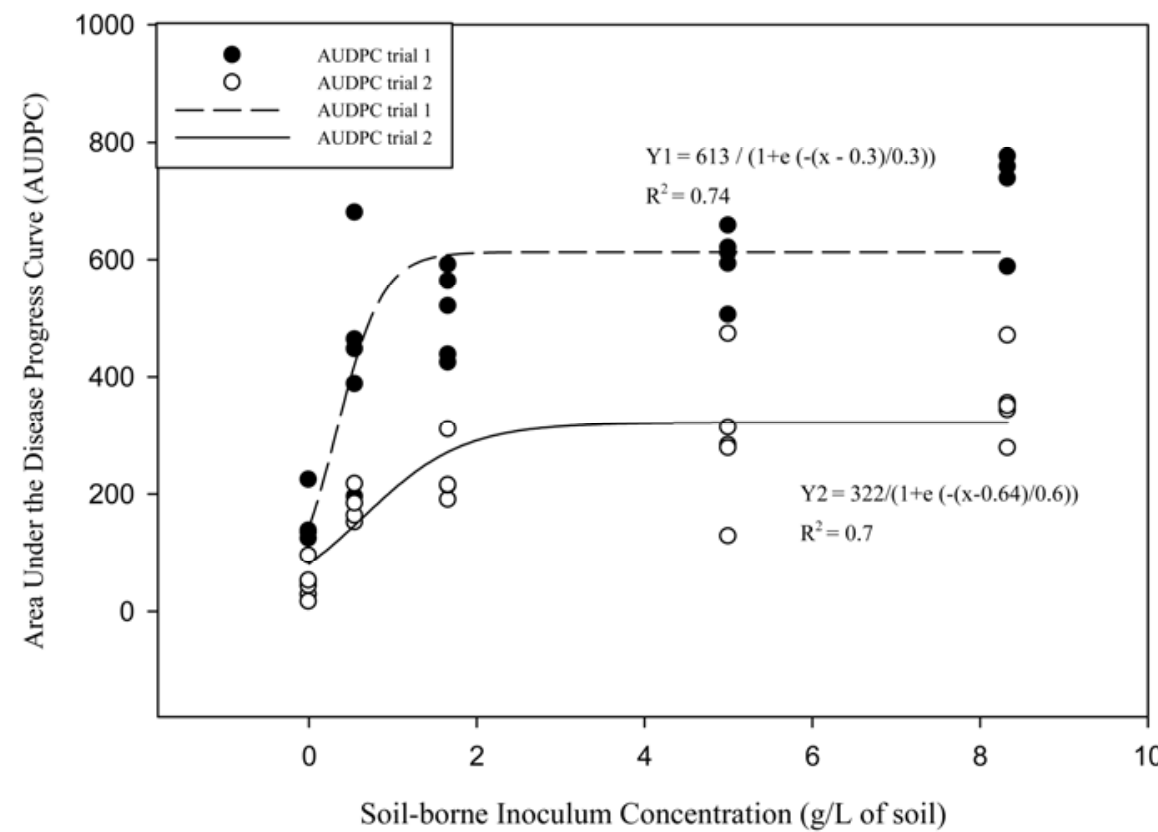

Fig. 1. Sigmoid relationship between soilborne inoculum concentration and the development of chlorosis and necrosis on the foliage (area under the disease progress curve). The trials were carried out with five replications per treatment. The concentrations of soilborne inoculum tested were $0,0.5,1.7$, 5 , and $8.3 \mathrm{~g}$ of infected rye grains per 1 liter of soil. Regression analysis was carried out in Sigma Plot (Sigma Plot Version 10; Systat Software Inc.) at $\alpha=0.05$. oculum sources of $C$. coccodes did not affect potato black dot severity.

Soilborne and seed tuber inocula of $C$. coccodes differ. Soilborne inoculum consists mostly of sclerotia, which must germinate, produce appressoria, and penetrate host tissue for infection and colonization to occur (38). Tuberborne inoculum may be external, on the epidermis as sclerotia $(19,35)$, or internal, in the vascular bundles associated with the stolon end as hyphae $(11,35)$. Internal seed-tuber inoculum possibly develops with the growing plant. Sclerotia on tubers germinate and produce appressoria infecting roots, stolons, and crowns through the external surface. The mode of infection of the later is similar to that of soilborne inoculum. Sclerotia on the surface of the tuber may germinate inward, into the tuber, to infect the plant. However, application of Prochloraz (mycelial growth inhibitor) reduced infection substantially (8), indicating that this mode of infection is not likely to occur. Soilborne inoculum is potentially more aggressive than tuberborne, probably because it is often spread throughout the soil profile and infects the roots in multiple infection courts, resulting in more damage. Tuberborne inoculum, on the other hand, probably acts as a single infection source.

Sclerotial development on stems was recorded as the length of the stem from the soil surface on which sclerotia were visible. This measurement proved to be a useful quantification technique for black dot severity $(25,29)$. Sclerotia on dried plant tissues indicate colonization of the fungus in the host tissue. C. coccodes has consistently been isolated from dried potato stems and roots with sclerotia but not from adjacent dried tissues not bearing sclerotia (unpublished data).

Isolates C56 and C59 both are assigned to North American VCG2 (NA-VCG2; 29), indicating a common genetic background. Isolate C59 produced more sclerotia on the stem when inoculum originated from the soil than from the seed tuber (Tables 1 and 2). Also, isolate C59 produced more sclerotia on the stem than isolate C56 when inoculum arrived from the soil but not from the seed tuber (Tables 1 and 2). Stem colonization by isolates C56 and C59 differed when inoculum arrived from different sources. It is probable that levels of disease caused by different isolates are associated with their genetic background (29) as well as the sources of inoculum.

The second hypothesis proposed that black dot severity was positively related to the concentration of $C$. coccodes propagules in the soil. This is the first report on the relationship between soilborne inoculum concentrations and black dot severity. Komm and Stevenson (18) reported the association between tuber infection and final black dot severity. Their data indicated a linear association between the 
level of tuber infection on the surface and the level of disease. The present study presented a nonlinear trend between soilborne inoculum and black dot severity. Black dot severity did not continue to increase once the concentration of soilborne inoculum exceeded 0.5 or $1.7 \mathrm{~g} / \mathrm{liter}$.

Infective propagules of $C$. coccodes in the field are most likely sclerotia clustered on plant debris or free in the soil. Thus, in the present study, inoculum was prepared on rye grains where sclerotia were clustered. Each grain was an infective unit and the soilborne inoculation method used was similar to the natural infection process in the field. Under these conditions, severe black dot developed in the presence of a limited concentration of $C$. coccodes

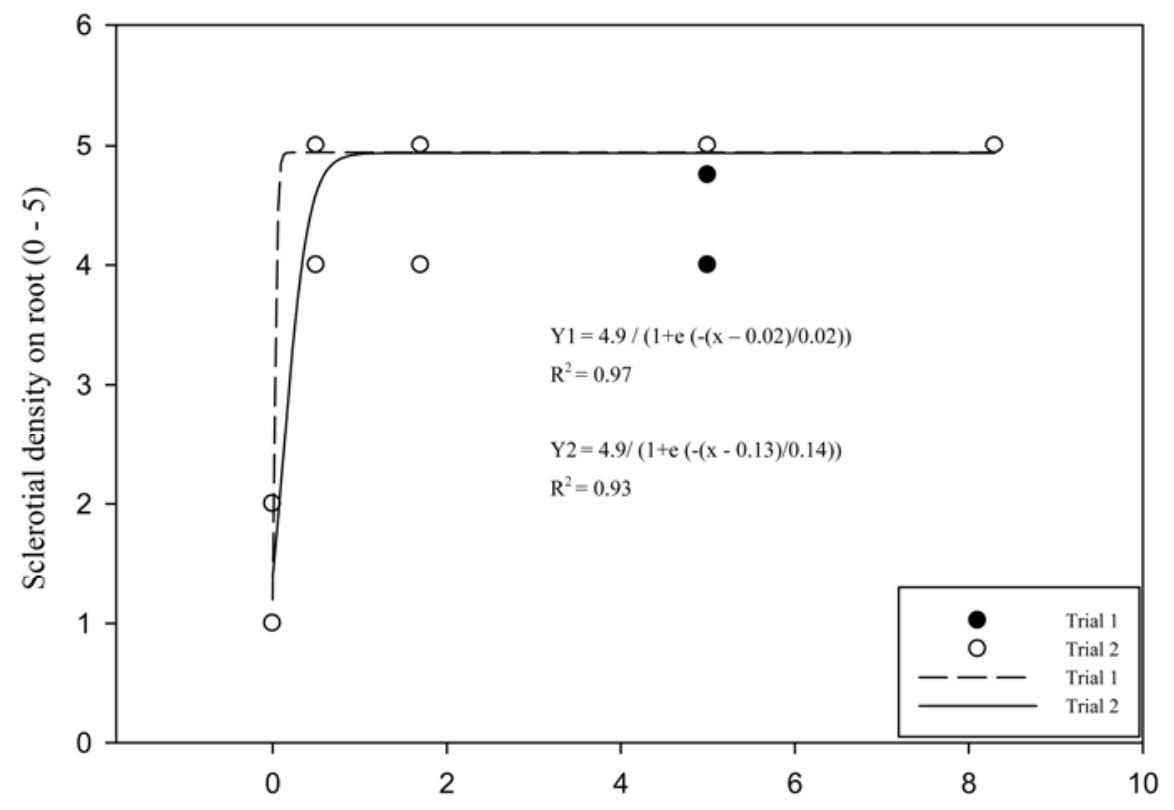

Soil-borne Inoculum Concentration (g / L of soil)

Fig. 2. Sigmoid relationship between soilborne inoculum concentration and sclerotial density on roots. The trials were carried out with five replications per treatment. The treatments were $0,0.5,1.7,5$, and $8.3 \mathrm{~g}$ of infected rye grains per 1 liter of soil. Here, some replications had similar disease severity value and their points are congruent; hence, the small number of points in the graph. Regression analysis was carried out in Sigma Plot (Sigma Plot Version 10; Systat Software Inc.) at $\alpha=0.05$.

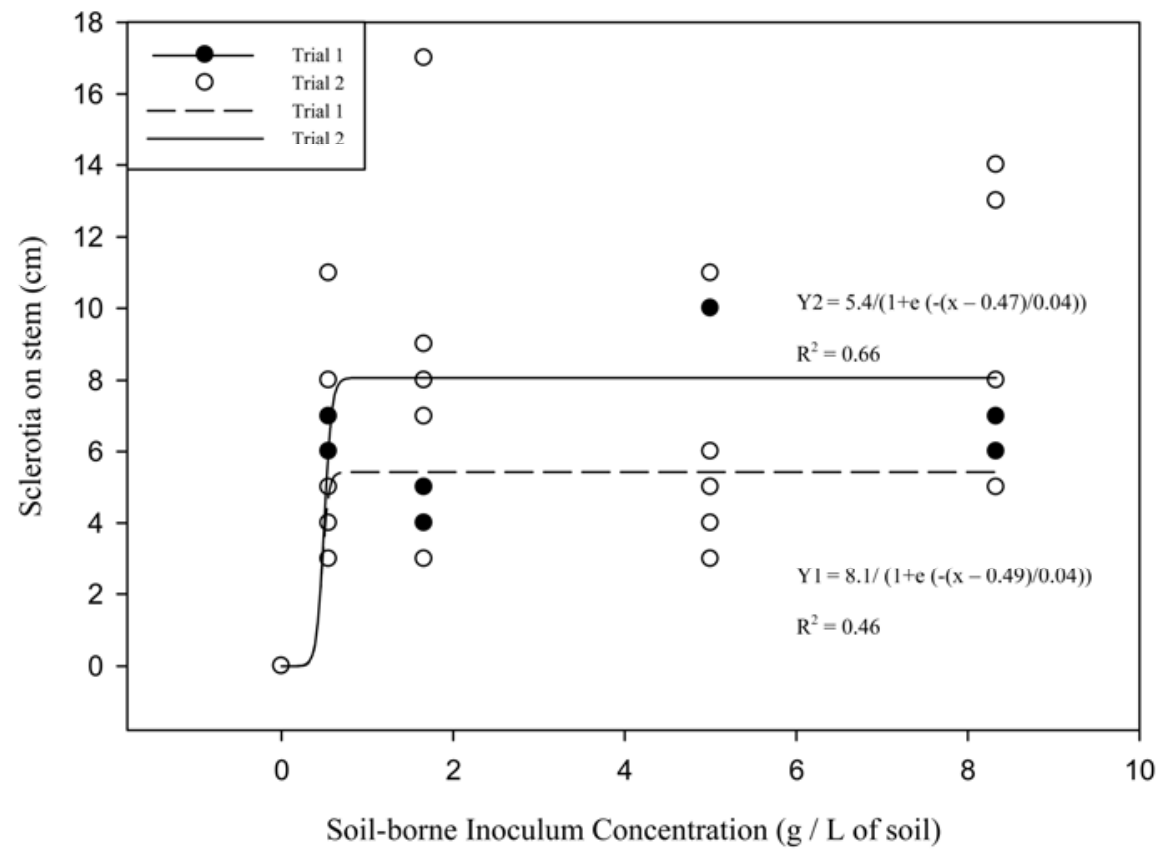

Fig. 3. Sigmoid relationship between soilborne inoculum concentration and the length of stems from the soil surface on which sclerotia were visible. The trials were carried out with five replications per treatment. The treatments were $0,0.5,1.7,5$, and $8.3 \mathrm{~g}$ of infected rye grains per 1 liter of soil. Regression analysis was carried out in Sigma Plot (Sigma Plot Version 10; Systat Software Inc.) at $\alpha=0.05$.

propagules in the soil. An upper threshold for soilborne inoculum was observed in that disease severity did not continue to increase once a certain level of inoculum was achieved. The quantity of the upper and lower disease thresholds was not determined in this study.

The relative importance of soilborne inoculum and its capability to cause severe disease with a narrow range of concentrations was demonstrated in this study. The management of $C$. coccodes propagules in the soil will be challenging. To date, no soil fumigant is commercially available to economically reduce $C$. coccodes, which leaves limited management options with fungicides $(8,21,23)$, crop rotations $(5,27)$, and resistant cultivars. The efficacy of strobilurin-based fungicides to control black dot is high but they have not consistently increased plant yields (23). In addition, resistance to strobilurin-based fungicides has been reported in Alternaria spp. $(20,30)$, suggesting the risk of resistance to the fungicide building up in populations of C. coccodes. Crop rotations with wheat, barley, maize, and pea that are poor hosts of the fungus $(5,27)$ is available. However, rotations should be long because sclerotia may survive in the soil up to 8 years (10), which makes this approach economically challenging. Under these conditions, black-dot-resistant potato cultivars seem to be the most sustainable option. Field resistance to black dot on tubers has been documented (32), and field resistance to stem colonization has been recently reported in potato germplasm (24). Resistance may become the most sustainable management strategy for black dot regardless of the inoculum sources and their potential aggressiveness.

\section{ACKNOWLEDGMENTS}

We thank the Washington State Potato Commission for supporting this research. The following manuscript was assigned Plant Pathology new series no. 0464, Department of Plant Pathology, College of Agricultural, Human, and Natural Resource Sciences Research Center, Project no. 0678, Washington State University, Pullman 99164-6430.

\section{LITERATURE CITED}

1. Andrivon, D., Lucas, J. M., Guérin, C., and Jouan, B. 1998. Colonization of roots, stolons, tubers and stems of various potato (Solanum tuberosum) cultivars by the black-dot fungus Colletotrichum coccodes. Plant Pathol. 47 (4):440-445.

2. Andrivon, D., Ramage, K., Guerin, C., Lucas, J. M., and Jouan, B. 1997. Distribution and fungicide sensitivity of Colletotrichum coccodes in French potato-producing areas. Plant Pathol. 46:722-728.

3. Barkdoll, A. W., and Davis, J. R. 1992. Distribution of Colletotrichum coccodes in Idaho and variation in Pathogenicity on potato. Plant Dis. 76:131-135.

4. Campbell, C. L., and Madden, L. V. 1990. Introduction to Plant Disease Epidemiology. A Wiley Interscience Publication. John Wiley \& Sons.

5. Celetti, M. J. 1990. A note on the incidence of soilborne fungi in six crops used in rotation with potatoes. Phytoprotection 71:97-100. 
6. Chesters, C. G. C., and Hornby, D. 1965. Studies on Colletotrichum coccodes. I. The taxonomic significance of variation in isolates from tomato roots. Trans. Br. Mycol. Soc. 48:573-581.

7. Dashwood, E. P., Fox, R. A., and Perry, D. A. 1992. Effect of inoculum source on root and tuber infection by potato blemish disease fungi. Plant Pathol. 41:215-223.

8. Denner, F. D. N., Millard, C., Geldenhuys, A., and Wehner, F. C. 1997. Treatment of seed potatoes with Prochloraz for simultaneous control of silver scuf and black dot on progeny tubers. Potato Res. 40:221-227.

9. Denner, F. D. N., Millard, C. P., and Wehner, F. C. 1998. The effect of seed- and soil-borne inoculum of Colletotrichum coccodes on the incidence of black dot on potato. Potato Res. 41:51-56.

10. Dillard, H. R., and Cobb, A. C. 1998. Survival of Colletotrichum coccodes in infected tomato tissue and soil. Plant Dis. 82:235-238.

11. Ducomet, V. 1908. Une nouvelle maladie de la pomme de terrre: la 'dartose'. Ann. Ecole Natl. Agric. Rennes 2:24-47.

12. Heilmann, L., Nitzan, N., Johnson, D. A., Pasche, J. S., and Gudmestad, N. C. 2006. Genetic variability in the potato pathogen Colletotrichum coccodes as determined by AFLP and vegetative compatibility group analyses. Phytopathology 96(10):1097-1107.

13. Jeger, M. J., Hide, G. A. Van den Boogert, P. H. J. F., Termorshuizen, A. J., and Van Baarlen. P. 1996. Pathology and control of soil-borne fungal pathogens of potato. Potato Res. 39:437-469.

14. Johnson, D. A. 1994. Effect of foliar infection by Colletotrichum coccodes on yield of russet Burbank potato. Plant Dis. 78:1075-1078.

15. Johnson, D. A., and Miliczky, E. R. 1993. Effects of wounding and wetting duration on infection of potato foliage by Colletotrichum coccodes. Plant Dis. 77:13-17.

16. Johnson, D. A., and Miliczky, E. R. 1993. Distribution and development of black dot, Verticillium wilt, and powdery scab on Russet Burbank potatoes in Washington State. Plant Dis. 77:74-79.

17. Johnson, D. A., Rowe, R. C., and Cummings, T. F. 1997. Incidence of Colletotrichum coc- codes certified potato seed tubers planted in Washington State. Plant Dis. 81:1199-1202.

18. Komm, D. A., and Stevenson, W. R. 1978. Tuber-borne infection of Solanum tuberosum 'superior' by Colletotrichum coccodes. Plant Dis. Rep. 62:682-687.

19. Lees, A. K., and Hilton, A. J. 2003. Black dot (Colletotrichum coccodes): an increasingly important disease of potato. Plant Pathol. 52:312.

20. Ma, Z., Felts, D., and Michailides, T. J. 2003. Resistance to azoxystrobin in Alternaria isolates from pistachio in California. Pestic. Biochem. Physiol. 77:66-74.

21. Marais, L. 1990. Efficacy of fungicides against Colletotrichum coccodes on potato tubers. Potato Res. 33:275-281.

22. Miller, J. S., and Hopkins, B. G. 2008. Checklist of a holistic potato health management plan. In: Potato Health Management. D. A. Johnson, ed. American Phytopathological Society. St. Paul, MN

23. Nitzan, N., Cummings, T. F., and Johnson, D. A. 2005. Effect of seed-tuber generation, soilborne inoculum, and azoxystrobin application on development of potato black dot caused by Colletotrichum coccodes. Plant Dis. 89:11811185.

24. Nitzan, N., Cummings, T., Johnson, D., Batchelor, D., Olsen, C., and Brown, C. 2008. Resistance to black dot in potato. Wash. State Potato Prog. 8(5):1-3.

25. Nitzan, N., Evans, M., and Johnson, D. A. 2006. Colonization of potato plants after aerial infection by Colletotrichum coccodes, causal agent of potato black dot. Plant Dis. 90:9991003.

26. Nitzan, N., Hazanovsky, M., Tal, M., and Tsror (Lahkim), L. 2002. Vegetative compatibility groups in Colletotrichum coccodes, the causal agent of black dot on potato. Phytopathology 92:827-832.

27. Nitzan, N., Lucas, B. S., and Christ, B. J. 2006. Colonization of rotation crops and weeds by the potato black dot pathogen Colletotrichum coccodes. Am. J. Potato Res. 83:503-507.

28. Nitzan, N., and Tsror (Lahkim), L. 2003. Effect of temperature and $\mathrm{pH}$ on in vitro growth rate and sclerotia density of Colleto- trichum coccodes isolates from different VCGs. Am. J. Potato Res. 80:335-339.

29. Nitzan, N., Tsror (Lahkim), L., and Johnson, D. A. 2006. Vegetative compatibility groups and aggressiveness of North American isolates of Colletotrichum coccodes, the causal agent of potato black-dot. Plant Dis. 90:1287-1292.

30. Pasche, J. S., Wharam, C. M., and Gudmestad, N. C. 2004. Shift in sensitivity of Alternaria solani in response to QoI fungicides. Plant Dis. 88:181-187.

31. Ratkowsky, D. A. 1990. Handbook of Nonlinear Regression Models. Marcel Dekker, Inc., New York.

32. Read, P. J. 1991. The susceptibility of tubers of potato cultivars to black dot (Colletotrichum coccodes (Wallr.) Hughes). Ann. Appl. Biol. 119:475-482.

33. Read, P. J., and Hide, G. A. 1988. Effect of inoculum source and irrigation on black dot disease of potato (Colletotrichum coccodes (Wallr.) Hughes) and its development during storage. Potato Res. 31:493-500.

34. Read, P. J., and Hide, G. A. 1995. Development of black dot disease (Colletotrichum coccodes (Wallr.) Hughes) and its effect on the growth and yield of potato plants. Ann. Appl. Biol. 127:57-72.

35. Tsror (Lahkim), L., Aharon, M., and Erlich, O. 1999. Survey of bacterial and fungal seedborne diseases in imported and domestic potato seed tubers 1. Phytoparasitica 27(3):1-12.

36. Tsror (Lahkim), L., Erlich, O., and Hazanovsky, M. 1999. Effect of Colletotrichum coccodes on potato yield, tuber quality, and stem colonization during spring and autumn. Plant Dis. 83:561-565.

37. Tsror (Lahkim), L., and Johnson, D. A. 2000 Colletotrichum coccodes on potato. Pages 362373 in: Colletotrichum-Host Specificity, Pathology and Host-Pathogen Interaction. D Prusky, S. Freeman, and M. B. Dickman, eds. The American Phytopathological Society Press, St. Paul MN.

38. Wang, J., and Higgins, V. J. 2005. Nitric oxide has a regulatory effect in the germination of conidia of Colletotrichum coccodes. Fungal Genet. Biol. 42:284-292.

39. Zar, Jerrold H. 1996. Biostatistical Analysis, 3rd ed. Prentice Hall, NJ. 